\section{Kovalchuk K., Katruk M., Tkachenko A., Guba L. Zakharchyn R.}

\title{
RESEARCH OF DESTRUCTION OF STARCH CRYSTAL STRUCTURE IN CUPCAKES WITH IMPROVED RECIPE
}

Вивчаємою проблематикою дослідження є прочес черствіння борошняних кондитерсъких виробів під час зберігання, що супроводжується комплексом складних фізико-хімічних, колоїних та біохімічних процесів, пов'язаних з крохмалем та білками. Виявлено, що науковщі використовують нетрадиційні добавки рослинного походження у кексах, зокрема, лікарські рослини, насіння, плоди і листя горіхів, овочі, фрукти, дикорослі ягоди. У роботі об'єктами дослідження були розроблені за авторськими рещептурами кекси «Кунжутний», «Морячок», «Міцний горішок», «Осінній аромат», «Чорничний», «Медок», «Елітний», базові зразки до порівняння - борошно вищого сорту і кекс «Столичний». У рещептурі цих кексів замінено частину пшеничного борошна на нетрадииійн сировину:

- «Кунжутний» (житне борошно, порошки листя ожини сизої, смородини чорної, квітів ромашки лікарської, молочна сироватка, кунжутна олія);

- «Морячок» (вівсяне борошно, порошки листя бадану товстолистого, малини, підбілу звичайного, слані ламінарії, олія гарбузового насіння);

- «Мічний горішок» (гречане борошно, порошки листя м'яти перцевої, волоського горіха, молочна сироватка, олія та ядра волоського горіха);

- «Осінній аромат» (кукурудзяне борошно, порошки трави звіробою звичайного, квітів липи серцелистої, ехінацеї пурпурової, сухе знежирене молоко, яблучно-вишневі иукати);

- «Чорничний» (гречане борошно, порошки коренів иикорію, квітів фіалки триколірної, сухе знежирене молоко, плоди чорничі сушені);

- «Медок» (кукурудзяне борошно, порошки квітів липи серцелистої, квітковий пилок, сухе знежирене молоко, олія гарбузового насіння, мед натуральний з пилком);

- «Елітний» (вівсяне борошно, листя м'яти перцевої, квасоля, прополіс, молочна сироватка, мед натуральний з прополісом).

У ході дослідження використано метод ренгенофазного аналізу на дифрактометрі ДРОН-УМ-1 (Росія), що виявляє ступінь та типи деформачії кристалічної структури речовин. Діапазон значень визначено при значеннях кутів відбиття в межах 10-30 - дифракційних максимумів крохмалю. Проаналізовано процес ретроградації на основі отриманих дифрактограм та підтверджено здатність використаних натуральних добавок у кексах подовжувати їх термін зберігання. В результаті випікання руйнування кристалічної структури крохмалю в розроблених зразках кексів відбувалося набагато інтенсивніше у порівнянні з контрольним зразком кексу «Столичний».

Ключові слова: борошняні кондитерські вироби, нетрадиційна сировина, кут дифракції, інтенсивність дифракиійного максимуму, ренгенофазний аналіз, рентгеноаморфна структура.

\section{Introduction}

Flour confectionery products are characterized by an almost complete absence of important biologically active substances, such as vitamins, carotenoids, dietary fiber, macroand micronutrients, etc. [1, 2], but their composition is subject to regulation [3]. The introduction of vegetable raw materials in the recipes, rich in useful essential substances, can effectively improve the chemical composition of flour products. It is in connection with this object of research are cupcakes, which will enrich the diet with micronutrients [4,5].
A review of literature shows that flour confectionery products are often used as an object of study in order to improve their consumer properties. Scientists practice partial replacement of wheat flour with rye, various types of gluten-free flour - corn, rice of various types and buckwheat [6]. Methods of using more unconventional flour, for example, lupine [7], from the roots of dandelion officinalis [8], from flax seeds [9] are also common. It is very effective to use fruit and vegetable powders from pomace, apple, apricot and pear puree in the formulation [10]. A method is proposed for using melon seeds [11], 
blueberry powder [12], and others. All these studies have shown the relevance and promise of using non-traditional plant materials with high biological value in confectionery recipes.

Another area of improving the consumer properties of flour confectionery products is the use of whey-based raw materials [13, 14] (low-lactose whey, demineralized, whey permeate, whey protein concentrates, whey protein isolates, lactose, calcium-fortified whey products).

An important stage in the life cycle of any product is its storage. Hardening is typical for flour confectionery products, which occurs due to a complex of complex physicochemical, colloidal, and biochemical processes associated with starch and proteins [15]. It is these substances that provide the formation of micropores with water molecules in an oriented state, the breaking of hydrogen bonds and the release of water change the structure, quality and taste of products. Organoleptic changes (decrease in volume, fragility of the product) in the quality of the product occurs due to the aging of starch, is accompanied by a loss of moisture and the transition of starch to a crystalline state [16]. During the study of the hardening process, the ratio of the crystalline and amorphous state of starch (retrograde) is very important. It is known that sugars bind water well in flour confectionery products; therefore, in the absence of sugars, products become stale faster [17].

The objects of research are developed according to the author's recipes: «Sesame», «Moriachok», «Mitsnyi Gorishok», «Osinnii Aromat», «Chornychnyi», «Medok», «Elitnyi» cupcakes, basic samples for comparison - premium flour and «Stolychnyi» cupcake. Various types of flour (buckwheat, oat, corn, rye), dairy products processing products (milk whey, skimmed milk powder) and beekeeping products (pollen, propolis, natural honey), and vegetable raw materials were introduced into the recipe for these cupcakes. The contents of the individual prescription components are presented in Table 1.

In the «Osinnii Aromat» cupcake, raisins are completely replaced with candied fruit (apple-cherry) and partially replaced in the «Mitsnyi Gorishok» cupcake with walnut kernels $(22.9 \mathrm{~kg} / \mathrm{t})$. In the «Chornychnyi» cupcake blueberries are used $(22.9 \mathrm{~kg} / \mathrm{t})$. Cupcakes with fillings contain $150.6 \mathrm{~kg} / \mathrm{t}$ each filling of natural honey with pollen «Medok» and natural honey with propolis «Elitnyi» [18].
The aim of research is studying the destruction degree of the starch crystal lattice in the structure of the pulp of the developed cupcakes, the interaction with other carbohydrates and their influence on the formation of the final crystal structure of the finished products.

\section{Methods of research}

To determine the phase composition of substances, an $\mathrm{X}$-ray phase analysis was used to reveal the degree of deformation of the crystal structure and the types of its defects. The study of the products was carried out on a DRON-UM-1 X-ray diffractometer (Russia), tube type 1.5 BSV23 Cu. Let's use samples of the studied cupcakes with a thickness of $2 \mathrm{~mm}$, the diffraction patterns were recorded under the conditions of the same area of the studied material and the radiation intensity. The values of the reflection angles ranged from $10-30^{\circ}$, this is due to the values of the diffraction maxima of starch [19].

The X-ray phase analysis method is based on the fact that for X-rays the crystal lattice is diffraction. If to use a powder or a crystalline material with variously oriented crystals as an object, then when interacting with it, monochromatic X-rays will always find for each sort of planes a certain number of crystals that fall into the reflection position. In this case, at a certain angle, a diffraction maximum for a given kind of planes will be observed. If the object under study consists of several phases, then each phase will have its own diffraction pattern. In this case, the diffraction patterns are the superposition of the diffraction patterns of all phases in the sample under study, the intensity of the reflections of each phase will depend on its amount in the mixture under study [20].

\section{Research results and discussion}

The main component of wheat flour is starch, when heated, it adsorbs water, because of which its crystalline structure is destroyed. It is determined that the diffraction patterns of flour (Fig. 1) consist of five broad high-intensity maxima corresponding to the structure of crystalline starch.

The diffraction patterns of the control sample cupcake «Stolychnyi» is shown in Fig. 2, $a$, where one can see very similar diffraction maxima to a higher-grade flour sample, but of much lower intensity.

Table 1

Features of the recipe composition of new cupcakes

\begin{tabular}{|c|c|c|c|c|c|c|c|}
\hline \multirow{2}{*}{$\begin{array}{l}\text { Unconventional } \\
\text { raw materials and } \\
\text { natural additives }\end{array}$} & \multicolumn{7}{|c|}{ The amount of raw materials in the cupcake recipe, $\mathrm{kg} / \mathrm{t}$} \\
\hline & «Sesame» & «Moriachok» & $\begin{array}{l}\text { «Mitsnyi } \\
\text { Gorishok» }\end{array}$ & $\begin{array}{l}\text { «Dsinnii } \\
\text { Aromat» }\end{array}$ & «Chornychnyi» & «Medok» & «Elitnyi» \\
\hline Flour & $\begin{array}{l}\text { rye } \\
(57.2)\end{array}$ & $\begin{array}{l}\text { oatmeal } \\
(38.1)\end{array}$ & $\begin{array}{l}\text { buckwheat } \\
\text { (19.06) }\end{array}$ & $\begin{array}{c}\text { corn } \\
(57.2)\end{array}$ & $\begin{array}{c}\text { buckwheat } \\
\text { (15.25) }\end{array}$ & $\begin{array}{c}\text { corn } \\
(53.06)\end{array}$ & $\begin{array}{l}\text { oatmeal } \\
(35.52)\end{array}$ \\
\hline $\begin{array}{l}\text { Powders and } \\
\text { mixtures thereof }\end{array}$ & $\begin{array}{c}\text { blackberry leaves } \\
\text { with gray (1.9), } \\
\text { black currant (3.8), } \\
\text { chamomile flowers } \\
\text { (1.9) }\end{array}$ & $\begin{array}{c}\text { fankincense leaves } \\
\text { (0.95), raspberries } \\
\text { (1.9), Foalfoot ordi- } \\
\text { nary (19.1), thallus } \\
\text { kelp (0.95) }\end{array}$ & $\begin{array}{c}\text { peppermint } \\
\text { leaves (1.91), } \\
\text { walnut (1.91) }\end{array}$ & $\begin{array}{c}\text { Hypericum per- } \\
\text { foratum (1.91), } \\
\text { linden blossoms } \\
\text { (1.91). Echinacea } \\
\text { purpurea (0.95) }\end{array}$ & $\begin{array}{c}\text { chicory roots } \\
\text { (0.95), tricolor- } \\
\text { lirni violet } \\
\text { flowers (5.7) }\end{array}$ & $\begin{array}{l}\text { heart-shaped } \\
\text { linden flowers } \\
\text { (1.77), flower } \\
\text { pollen (4.42) }\end{array}$ & $\begin{array}{c}\text { peppermint } \\
\text { leaves (1.77), } \\
\text { beans (13.69), } \\
\text { propolis (3.69)) }\end{array}$ \\
\hline Milk serum & 38.1 & - & 38.12 & - & - & 53.05 & 53.29 \\
\hline $\begin{array}{l}\text { Skimmed milk } \\
\text { powder }\end{array}$ & - & - & - & 38.12 & 57.2 & - & - \\
\hline Vegetable oils & $\begin{array}{l}\text { sesame seeds } \\
\text { (21.0) }\end{array}$ & $\begin{array}{l}\text { pumpkin seeds } \\
\text { (16.3) }\end{array}$ & walnut (21.0) & - & - & $\begin{array}{l}\text { pumpkin seeds } \\
\text { (15.12) }\end{array}$ & - \\
\hline
\end{tabular}


Such data confirm the partial destruction of the lattice of the starch molecule. It is revealed that the intensity of the reflection maximum, which corresponds to a diffraction angle of $20^{\circ}$ for the Stolychnyi cupcake, is 295 .

Fig. 2, $b$ shows the results of an X-ray phase study of the «Sesame» cupcake. A decrease in diffraction maxima and their intensity is revealed in comparison with the control sample. The decrease in the destruction of the crystalline structure of starch is due to the partial replacement of wheat flour with rye and the addition of whey, increases the content of monosugars. The intensity of the maximum reflection for the «Sesame» cupcake is only 200.

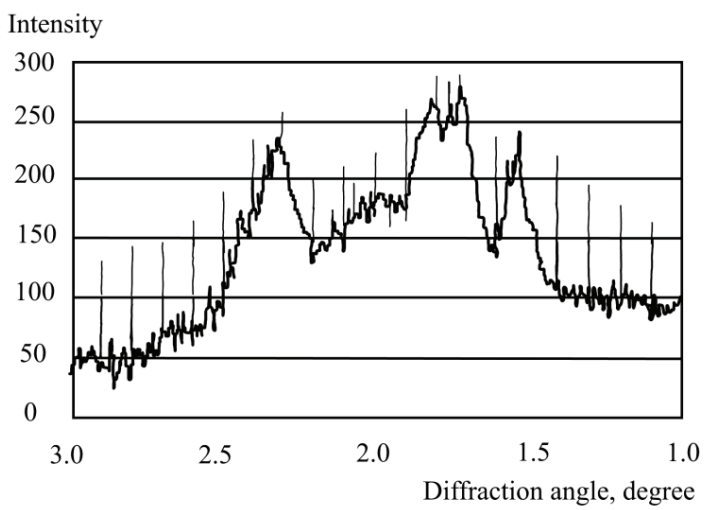

Fig. 1. Diffraction pattern of premium wheat flour
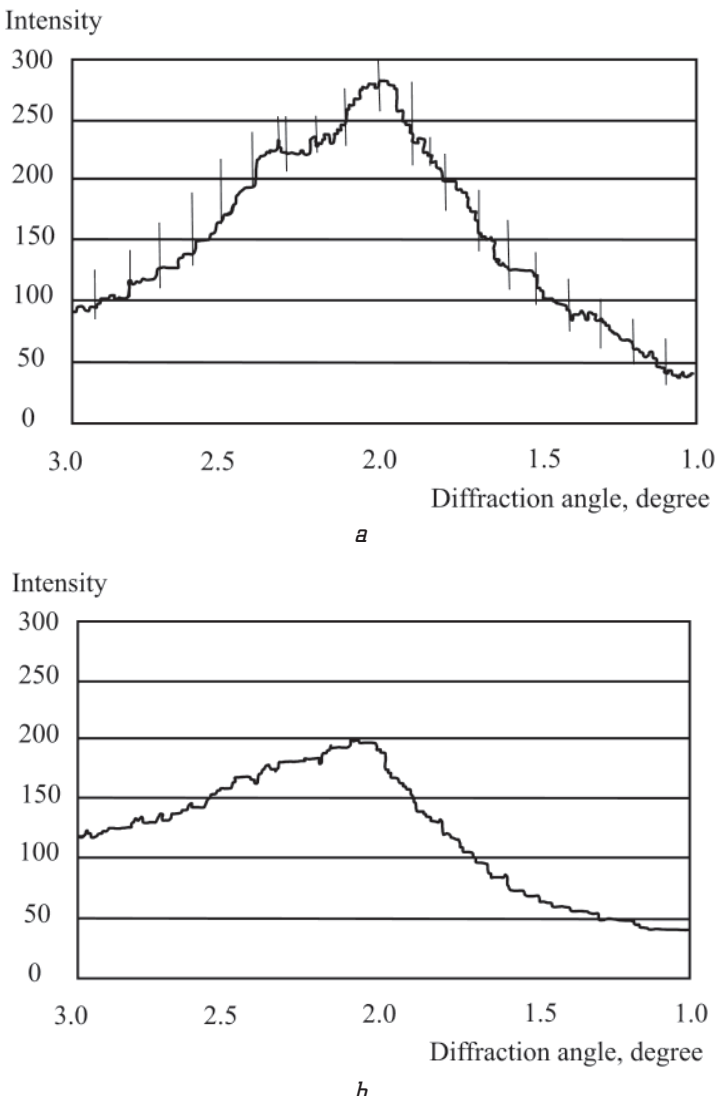

b

Fig. 2. Diffraction patterns after baking: $a$ - control sample cupcake; $b-$ «Sesame» cupcake

From the diffractogram of the «Moriachok» cupcake (Fig. 3, a), it can be concluded that, as a result of baking, the destruction of the crystalline structure of starch occurred much more intensively compared to the control sample. This trend can be explained by the partial introduction of oatmeal in the recipe. The intensity of diffraction maxima for the «Moriachok» cupcake is 255 .

The «Mitsnyi Gorishok» cupcake (Fig. 3, b) is characterized by a well-defined X-ray amorphous structure. It is buckwheat flour and whey that increase the content of simple carbohydrates, and therefore accelerate the destruction of the crystalline structure of starch in this product.
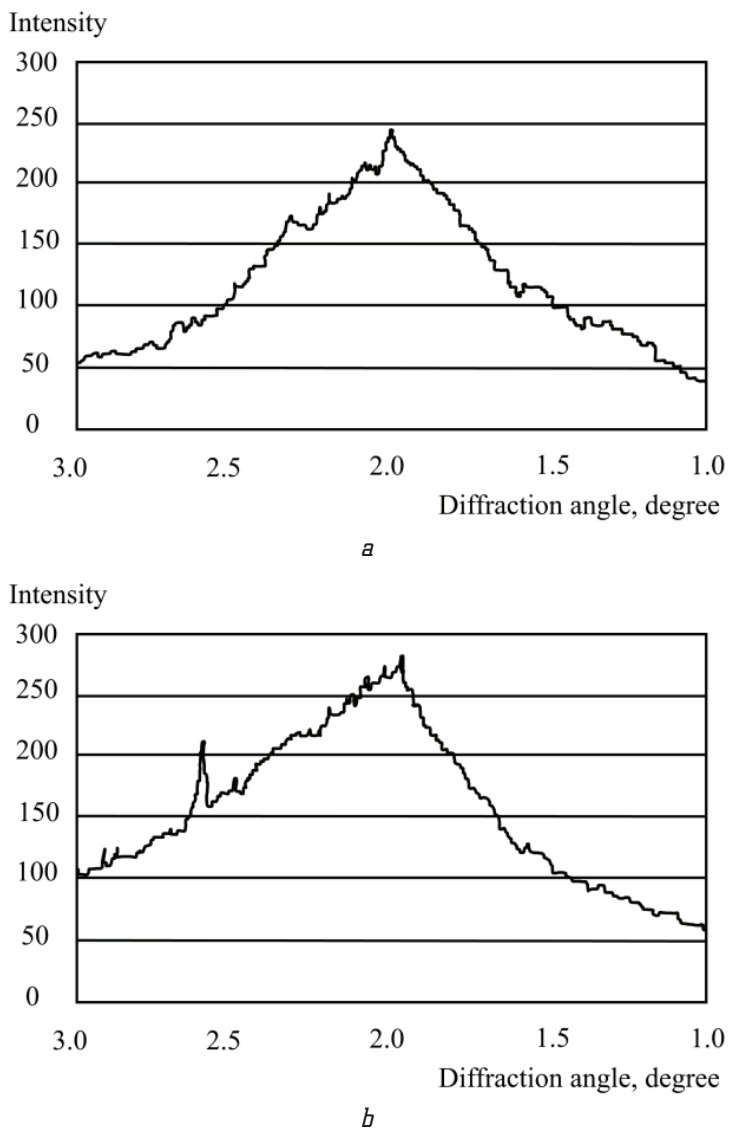

Fig. 3. Diffraction patterns after baking:

a - «Moriachok» cupcake; $b$ - «Mitsnyi Gorishok» cupcake

According to the diffraction pattern of the «Osinnii Aromat» cupcake (Fig. 4, $a$ ), a sharp increase in the diffraction maximum after baking is observed, and consequently, the destruction of the crystalline structure of starch occurred more intensively compared to the control sample.

Buckwheat flour, skimmed milk powder, and chicory root powder are added to the «Chornychnyi» cupcake (Fig. 4, $b$ ), which increases the water-holding ability of the product due to hydration of simple carbohydrate molecules of the introduced raw materials, as a result of which the cupcake is stale. At a diffraction angle of $20^{\circ}$, the intensity of the diffraction maximum in the «Chornychnyi» cupcake is 298 .

To the «Medok» cupcakes (Fig. 5, a) and «Elitnyi» (Fig. $5, b$ ) bee products are introduced. Milk whey, corn flour, pollen powder are added to the composition of the «Medok» cupcakes, and natural and flower pollen honey is added to the filling. «Elitnyi» cupcake contains milk whey, oatmeal, bean powder and propolis. The filling is formed on the basis of natural honey with propolis. 

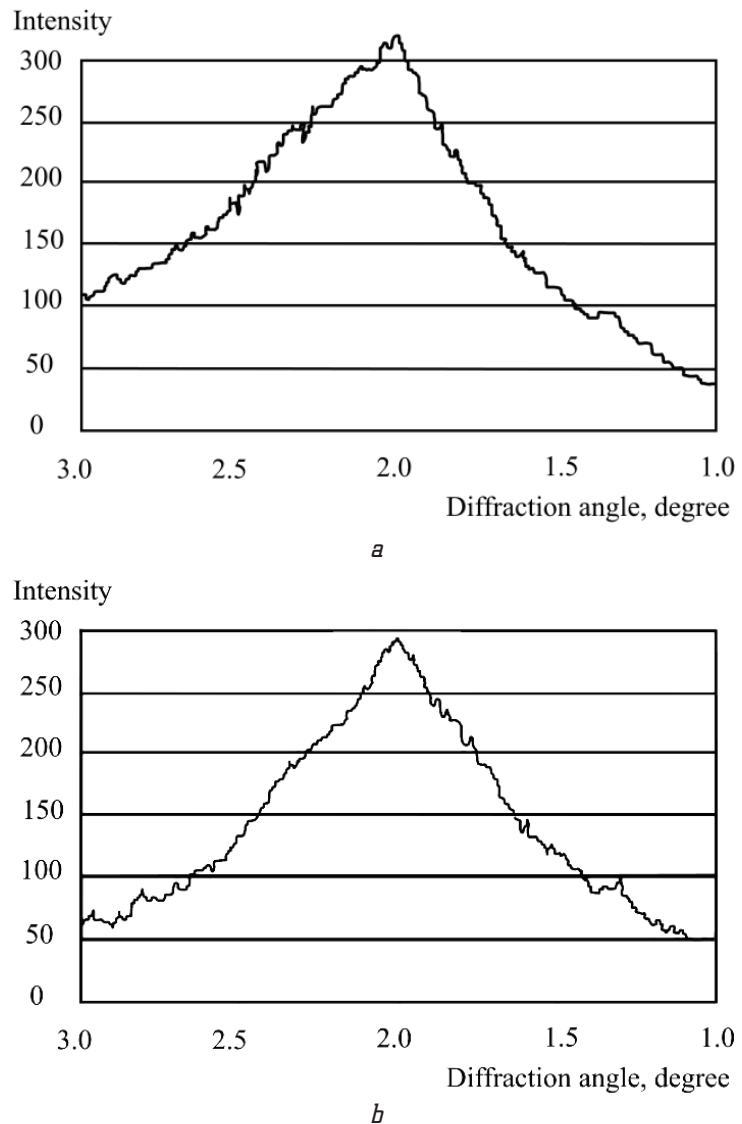

Fig. 4. Diffraction patterns after baking:

$a$ - «Dsinnii Aromat» cupcake; $b$ - «Chornychnyi» cupcake

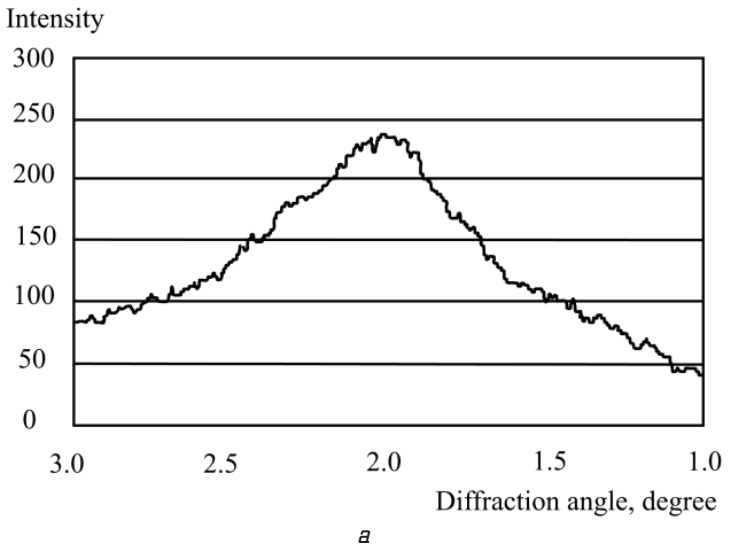

Intensity

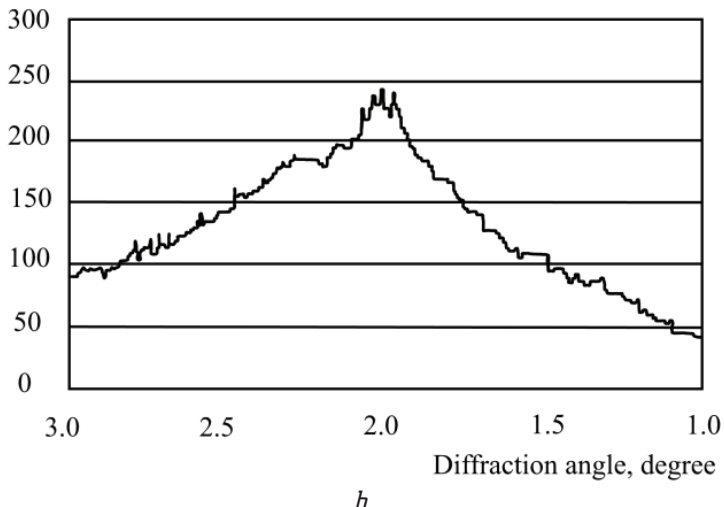

Fig. 5. Diffraction patterns after baking: $a$ - «Medok» cupcake; $b$ - «Elitnyi» cupcake
Beekeeping products increase the content of monosugars, which contributes to the release of water, interacting with flour proteins with the formation of gluten, as well as with starch, as a result of which its crystalline structure is destroyed.

When comparing the diffraction patterns of the «Elitnyi» cupcake sample with the diffraction patterns of the control sample, the destruction of the crystalline sections of the starch of flour, the intensity of the reflection maximum are clearly observed. This corresponds to a diffraction angle of $20^{\circ}$ for the «Elitnyi» cupcake sample, which is 225 . In the «Medok» and «Elitnyi» samples, the maxima are clearly delineated, and there are no diffraction, which indicates a slowdown in the retrograde process.

\section{Conclusions}

The phase composition of the substances is determined in the developed «Sesame», «Moriachok», «Mitsnyi Gorishok», «Osinnii Aromat», «Chornychnyi», «Medok», «Elitnyi» cupcakes from the X-ray analysis of X-ray phase analysis revealed the degree of deformation of the crystalline structure of starch, and therefore analyze the process of retrograde. Comparison of the obtained diffractograms with the control sample of the «Stolychnyi» cupcake confirms the efficiency of using the proposed plant materials and natural additives in the cupcakes. The additions determine the process of destruction of the crystalline structure of starch, and thus slow down the process of retrograde and lengthen the storage of cupcakes.

\section{References}

1. Dubcov, G. G., Dzhaboeva, A. S., SHaova, L. G. (2010). Novye vidy muchnykh konditerskikh izdelii profilakticheskogo naznacheniia. Konditerskoe $i$ khlebopekarnoe proizvodstvo, 1-2, 50

2. Ranadheera, R. D. C. S., Baines, S. K., Adams, M. C. (2010). Importance of food in probiotic efficacy. Food Research International, 43 (1), 1-7. doi: http://doi.org/10.1016/j.foodres.2009.09.009

3. Kozlova, O. S., Filippov, S. V. (2010). Naturalnye ingredienty dlia proizvodstva funkcionalnykh produktov. Konditerskoe $i$ khlebopekarnoe proizvodstvo, 10, 14-16.

4. Kuznecova, L. S., Sidanova, M. Iu. (2010). Novye netradicionnye vidy syria dlia konditerskoi promyshlennosti. Konditerskoe $i$ khlebopekarnoe proizvodstvo, 9, 8-10.

5. Dorokhovych, A., Soloviova, O., Bondaruk, Yu. (2010). Zbahachennia kondyterskykh vyrobiv vitaminamy i mineralnymy rechovynamy. Khlibopekarska i kondyterska promyslovist Ukrainy, $7-8$ (68-69), 57-60.

6. Vishniak, M. N. (2009). Muchnye konditerskie izdeliia dlia bezgliutenovogo pitaniia. Polzunozskii almanakh, 2, 95-96.

7. Paraskevopoulou, A., Provatidou, E., Tsotsiou, D., Kiosseoglou, V. (2010). Dough rheology and baking performance of wheat flour-lupin protein isolate blends. Food Research International, 43 (4), 1009-1016. doi: http://doi.org/10.1016/ j.foodres.2010.01.010

8. Strupan, E. A., Strupan, O. A., Korshunova, T. V.(2009). Pat No. 2355171 RU. Sposob polucheniia muki iz rastitelnogo syria. MPK: A 21 D 2/36. No. 2008106096/13; declareted: 18.02.2008; published: 20.05.2009.

9. Suprunova, I. A., Chizhikova, O. G., Samchenko, O. N. (2010) Muka lnianaia - perspektivnii istochnik pischevykh volokon dlia razrabotki funkcionalnykh produktov. Tekhnika i tekhnologiia pischevykh proizvodstv, 4, 50-54.

10. Perfilova, O. V., Baranov, B. A., Skripnikov, Iu. G. (2009). Frkuktovye i ovoschnye poroshki iz vyzhimok v konditerskom proizvodstve. Khranenie $i$ pererabotka selkhozsyria, 9, 52-54.

11. Franko, E. P., Kasianov, G. I. (2010). Osobennosti pererabotki miakoti i semian dyni. Izvestiia vuzov. Pischevaia tekhnologiia, 4 , $26-28$. 
12. Tumanova, A. E., Tipsina, N. N., Korshunova, T. V., Strupan, E. A. (2010). Poroshok iz cherniki - cennaia pischevaia dobavka. Konditerskoe i khlebopekarnoe proizvodstvo, 7-8, 50-52.

13. Kaloshyna, A., Vaskyna, V. (2011). Perspektyvi yspolzovanyia novoho molochnoho produkta $\mathrm{v}$ proyzvodstve kondyterskykh yzdelyi. Khlibopekarska i kondyterska promyslovist Ukrainy, 1 (74), 5.

14. Ramazanova, L. A., Daudova, T. N. (2009). Poluchenie i ispolzovanie kompleksnykh BAD na osnove molochnoi syvorotki. Khranenie i pererabotka selkhozsyria, 2, 63-65.

15. Lozova, T. M., Syrokhman, I. V. (2009). Naukovi osnovy for muvannia spozhyvnykh vlastyvostei $i$ zberihannia yakosti boroshnianykh kondyterskykh vyrobiv. Lviv: Vydavnytstvo Lvivskoi komertsiinoi akademii, 456.

16. Syrokhman, I. V., Dontsova, I. V. (2010). Suchasni napriamy polipshennia spozhyvnykh vlastyvostei zhyrovmisnykh kondyterskykh vyrobiv. Lviv: Vydavnytstvo Lvivskoi komertsiinoi akademii, 320.

17. Khasanova, S. D., Skobelskaia, Z. G. (2012). Izuchenie form sviazyvaniia vlagi $\mathrm{v}$ pomade so shrotom amaranta. Khranenie $i$ pererabotka selkhozsyria, 1, 26-28.

18. Kovalchuk, K., Ozimok, H., Mariychuk, R., Gyrka, O., Bodak, M., Palko, N. et. al. (2019). Determination of safety indicators in the developed muffins with non-traditional raw materials. EUREKA: Life Sciences, 4, 28-35. doi: http://doi.org/ 10.21303/2504-5695.2019.00972

19. Shulha, O. S. (2019). Naukove obgruntuvannia ta rozroblennia tekhnolohii biodehradabelnoho yistivnoho pokryttia dlia kondyterskykh $i$ khlibobulochnykh vyrobiv. Kyiv, 45.
20. Zubenko, V. V. (1992). Eksperimentalnye metody rentgenostrukturnogo analiza. Moscow: Izdatelstvo MGU, 150.

Kovalchuk Khrystyna, PhD, Associate Professor, Department of Com modity Research and Commodity Expertise, Lviv Institute of Economics and Touris, Ukraine, e-mail: khristinakovalchuk@i.ua, ORCID: http:// orcid.org/0000-0001-6894-9392

Katruk Mariia, PhD, Assistant, Department of Entrepreneurship and Marketing, Ukrainian Academy of Printing, Lviv, Ukraine, e-mail: katrukmariya@i.ua,ORCID: http://orcid.org/0000-0002-8780-5527

Tkachenko Alina, PhD, Associate Professor, Department of Commodity Research, Biotechnology, Examination and Customs, Higher Educational Institution of Ukoopsoyuz «Poltava University of Economics and Trade»,Ukraine,e-mail:alina_biaf@ukr.net, ORCID: http:// orcid.org/0000-0001-5521-3327

Guba Lyudmila, PhD, Associate Professor, Department of Commodity Research, Biotechnology, Examination and Customs, Higher Educational Institution of Ukoopsoyuz «Poltava University of Economics and Trade», Ukraine, e-mail: lyudmika@gmail.com, ORCID: http:// orcid.org/0000-0003-1008-6023

Zakharchyn Roman, PhD, Associate Professor, Department of Commodity Research and Commodity Expertise, Lviv Institute of Economics and Touris,Ukraine, e-mail: romzakharchin@i.ua, ORCID: http:// orcid.org/0000-0003-0003-7287 